\title{
IONIC CONDUCTIVITY OF E-BEAM DEPOSITED YTTRIUM STABILIZED ZIRCONIA THIN FILMS *
}

\author{
G. Laukaitis ${ }^{\text {a }}$, J. Dudonis ${ }^{\text {a }}$, O. Liukpetryte ${ }^{\text {a }}$, A.F. Orliukas ${ }^{\text {b }}$, and D. Milčius ${ }^{\mathrm{c}}$ \\ ${ }^{a}$ Physics Department, Kaunas University of Technology, Studentu 50, LT-51368 Kaunas, Lithuania \\ E-mail: giedrius.laukaitis@ktu.lt, julius.dudonis@ktu.lt \\ ${ }^{\mathrm{b}}$ Faculty of Physics, Vilnius University, Saulètekio 9, LT-10222 Vilnius, Lithuania \\ E-mail: antanas.orliukas@ff.vu.lt \\ ${ }^{\mathrm{c}}$ Lithuania Energy Institute, Breslaujos 3, LT-44403 Kaunas, Lithuania \\ E-mail: milcius@isag.lei.lt
}

Received 15 June 2007; revised 25 September 2007; accepted 21 November 2007

\begin{abstract}
In the present study yttrium stabilized zirconia (YSZ) thin films were deposited on the Alloy-600 and optical quartz substrates using e-beam deposition technique with controlled deposition parameters: substrate temperature $\left(T_{\mathrm{s}}\right)$ and electron gun power $(P)$ influencing the thin film deposition mechanism. The dependence of these parameters on thin film ionic conductivity, structure, and surface morphology was investigated by X-ray diffraction and scanning electron microscopy (SEM). It was found that electron gun power has the influence on the crystallite size, texture, and roughness of YSZ films. Dominating dispersion in the deposited YSZ thin films (substrate temperature $T=250{ }^{\circ} \mathrm{C}$, e-beam gun power $P=0.9 \mathrm{~kW}$ ) relates to ionic transport in the crystallites in the measured frequency and temperature ranges. The measured values of conductivity and its activation energies are those typical of the polycrystalic $\mathrm{ZrO}_{2}-8 \mathrm{~mol} \% \mathrm{Y}_{2} \mathrm{O}_{3}$ compound. The conductivity values of crystallites of YSZ thin films and ceramics are similar. Differences are found only in thin films deposited at $T=250{ }^{\circ} \mathrm{C}$ and $P=0.66 \mathrm{~kW}$.
\end{abstract}

Keywords: YSZ thin films, ionic conductivity, solid oxide fuel cells (SOFC), electron beam deposition

PACS: 81.15.Jj, 66.30.Dn, 82.47.Ed, 73.61.-r

\section{Introduction}

The solid electrolyte with oxygen vacancy $\left(\mathrm{V}_{\mathrm{O}}^{* *}\right)$ demonstrating fast ion transport emerged as an attractive material for applications in solid oxide fuel cells (SOFC). It is known that $\mathrm{ZrO}_{2}$ stabilized by $8 \mathrm{~mol} \%$ $\mathrm{Y}_{2} \mathrm{O}_{3}$ (YSZ) belongs to cubic symmetry with the lattice parameter $a=0.5137 \mathrm{~nm}$ [1] and has maximum value of ionic conductivity, as well as good chemical and thermal stability. The total ionic conductivity $\sigma_{\mathrm{t}}$ of YSZ ceramics was found to be $2.5 \cdot 10^{-2} \mathrm{~S} / \mathrm{m}$ at the temperature $T=800 \mathrm{~K}$ and their activation energy was $\Delta E_{\mathrm{t}}=1.04 \mathrm{eV}$ [2]. The first SOFC generation has been prepared by the tape casting and the sintering method. The acceptable resistance of thick electrolytes for such SOFC can be reached at a very high operating temperatures $(1173-1273 \mathrm{~K})$ [3]. Today it is widely accepted that lowering the operating temperature of SOFC in the range of $900-1000 \mathrm{~K}$ is preferable for several reasons. The problem can be solved

\footnotetext{
* The report presented at the 37th Lithuanian National Physics Conference, 11-13 June 2007, Vilnius, Lithuania.
}

using YSZ thin films. A variety of chemical and physical methods, such as MOCVD, CVD, spray pyrolysis, PLD, PVD for producing solid oxide electrolyte thin films exists $[4,5]$.

Technological conditions for YSZ thin film deposition by e-beam technique, the results of investigations of X-ray diffraction, scanning electron microscope (SEM) and ionic conductivity, and dielectric permittivity conducted in air by the impedance spectrometer in the frequency range from $2 \cdot 10^{3}$ to $10^{6} \mathrm{~Hz}$ are presented in this paper.

\section{Experiment}

YSZ thin films were deposited with e-beam deposition technique from $\mathrm{ZrO}_{2}$ stabilized by $8 \mathrm{~mol} \%$ of $\mathrm{Y}_{2} \mathrm{O}_{3}$ (8YSZ) ceramic powder (SIGMA-ALDRICH submicron powder, $99.9 \%$ purity based on trace metal analysis, $1.68 \mu \mathrm{m}$ average particle size). YSZ powder was pressed to the pellets of $25 \mathrm{~mm}$ diameter and $2 \mathrm{~mm}$ thickness before deposition. YSZ thin films (1.5$2 \mu \mathrm{m}$ thick) were deposited on Alloy-600 (Fe-Ni-Cr) 
and optical quartz $\left(\mathrm{SiO}_{2}\right)$ at different substrate temperatures and e-beam power (deposition rates). The samples were cleaned in the ultrasonic bath (pure acetone) before deposition. E-beam deposition technique system was used. More details on the technical parameters and experimental equipment of the used technique are presented in [6]. Residual gas pressure in the vacuum chamber was $4 \cdot 10^{-3} \mathrm{~Pa}$. The distance between electron gun and substrate was fixed at $240 \mathrm{~mm}$. The substrate was additionally heated by a heater to the temperatures from 20 to $600^{\circ} \mathrm{C}$. The deposition rate was evaluated from the thin film thickness measurements.

The film structure was analysed by X-ray diffraction (XRD) (DRON-UM1 with standard Bragg-Brentan focusing geometry) using $\mathrm{Cu} \mathrm{K}_{\alpha}$ radiation (wavelength $0.154247 \mathrm{~nm}$ ). The crystallite size $d$ of YSZ thin films was estimated from the Scherrer's equation [7].

YSZ thin films deposited on substrate Alloy-600 were used for the electrical measurements. Platinum electrodes were prepared on thin films by applying a conductive platinum paste fired at $1073 \mathrm{~K}$. The Pt leads from two electrodes were connected via coaxial cable to a PC-controlled Precision LCR Meter 4284 A. The two-probe AC measurements of complex conductivity $\tilde{\sigma}=\sigma^{\prime}+\mathrm{i} \sigma^{\prime \prime}$, complex impedance $\tilde{Z}=Z^{\prime}+\mathrm{i} Z^{\prime \prime}$, and complex dielectric permittivity $\tilde{\varepsilon}=\varepsilon^{\prime}+\mathrm{i} \varepsilon^{\prime \prime}$ were performed between room temperature and $1000 \mathrm{~K}$ in CpRp mode (capacitance and resistance connected in parallel).

\section{Results and discussion}

YSZ thin films were deposited from tetragonal (t-YSZ) phase $\mathrm{ZrO}_{2}$ stabilized by $8 \mathrm{~mol} \%$ of $\mathrm{Y}_{2} \mathrm{O}_{3}$ (8YSZ) ceramic powders. The XRD diffraction patterns of the pressed YSZ powders are presented in [6]. It shows that the positions of the Bragg peaks are those typical of the tetragonal 8YSZ (according to Crystallographica Search-Match, Version 2). XRD peaks of YSZ thin films indicate sharp (101) and minor (110), (200), (211), and (202) orientations. These YSZ thin films repeat the crystal structure of the chosen evaporated YSZ material [6].

The temperature does not influence the crystal orientation when thin film is deposited on the different types of substrates and different types of powder (tetragonal and cubic) are used [6]. Crystallite size increases from 17 to $38 \mathrm{~nm}$ with the growth of substrate temperature from 200 to $600{ }^{\circ} \mathrm{C}$ (Fig. 1). The smallest crystallite size is found to be equal to $17.2 \mathrm{~nm}$ for the films deposited at $250{ }^{\circ} \mathrm{C}$ (for all types of substrates).

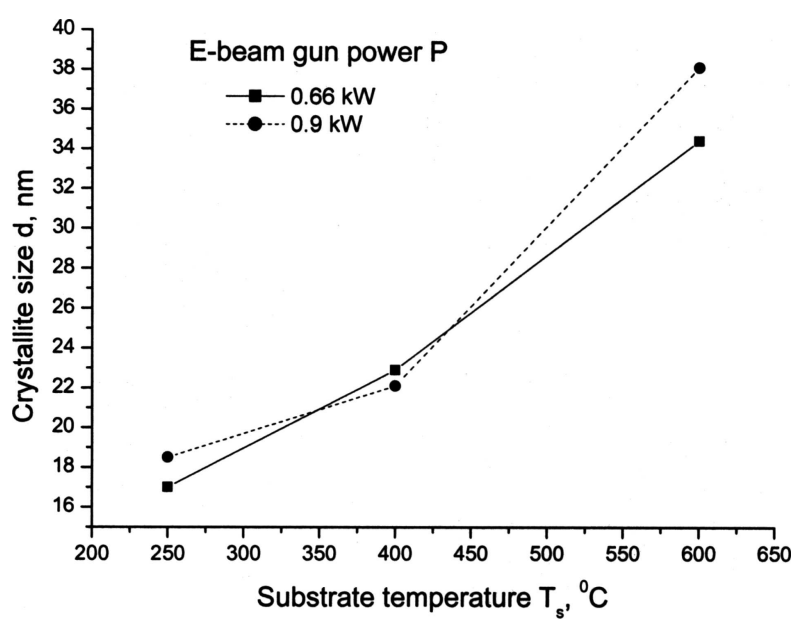

Fig. 1. YSZ thin film crystallites' size (extracted from XRD data) dependence on substrate temperature $T$ at different e-beam gun powers $P(0.66$ and $0.9 \mathrm{~kW})$.

It is necessary to know the dependence of growth rate on the e-beam gun power for controlling the crystallite size having influence on ionic conductivity. Crystallite size depends on growth rate of the YSZ film. The growth rate increases linearly with e-gun power varying in the range of $0.6-2.0 \mathrm{~nm} / \mathrm{s}$ [7]. The e-beam deposited YSZ films had good adhesion to the substrate. The films were uniform, shiny, and mirrorlike for lower growth rates $(<1.5 \mathrm{~nm} / \mathrm{s}$ and e-beam gun power $<1.0 \mathrm{~kW}$ ). Deposition process was found to be unstable and thin film started to be nonhomogeneous with cracks and bad adhesion to the substrate (Fig. 2) at higher e-beam power, when the growing rate was higher than $1.5 \mathrm{~nm} / \mathrm{s}$. For this reason, YSZ thin films grown at low e-beam gun powers $(0.66$ and $0.9 \mathrm{~kW})$ were chosen for the ionic conductivity and dielectric permittivity measurements.

Characteristic frequency dependences of the imaginary part of the complex impedance $\operatorname{Im}(\tilde{Z})$ and real part of complex conductivity $\operatorname{Re}(\tilde{\sigma})$ at different temperatures for YSZ thin film $\left(P=0.66 \mathrm{~kW}, T_{\mathrm{s}}=600{ }^{\circ} \mathrm{C}\right)$ are shown in Figs. 3(a) and 3(b) respectively. Two dispersion regions in $Z^{\prime \prime}$ and $\sigma^{\prime}$ spectra for investigated samples were found. Both processes are thermally activated and dispersion regions shift toward higher frequencies with the increase of temperature. The dispersion processes in the films could be related to $\mathrm{V}_{\mathrm{O}}^{* *}$ transport in the bulk and grain boundary of YSZ polycrystalline thin films [8].

The high frequency region of dispersions may be attributed to the relaxation processes in the bulk, while lower frequency part corresponds to grain boundary processes in the same way as in a wide range of other solid electrolyte ceramics [8-12]. 


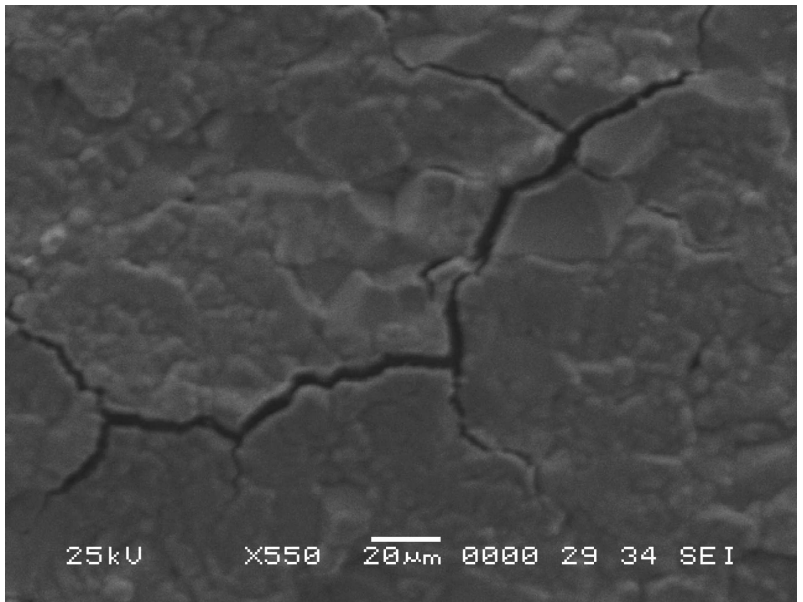

(a)

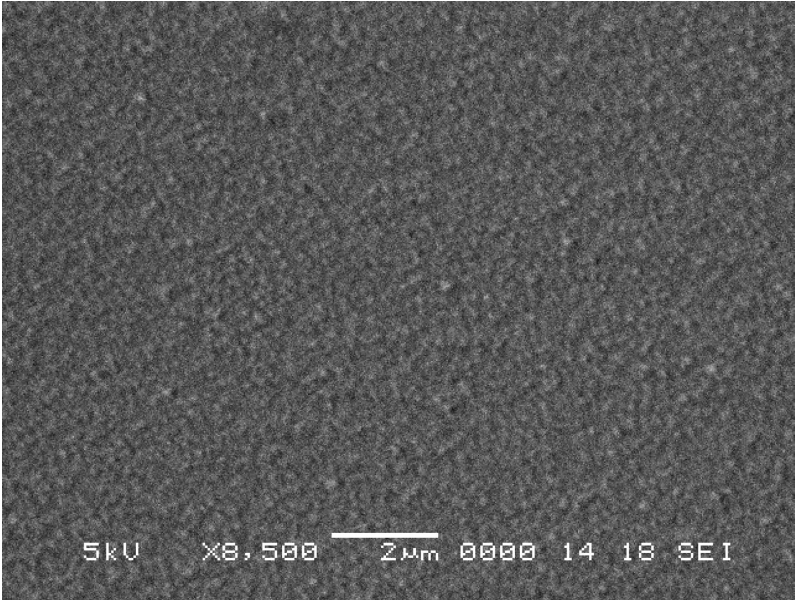

(b)

Fig. 2. SEM image of the surface of $\mathrm{YSZ}$ thin film deposited on $\mathrm{SiO}_{2}$ (substrate temperature $600{ }^{\circ} \mathrm{C}$ ) (a) at high e-beam gun power $(1.2 \mathrm{~kW}$ ), (b) at $0.75 \mathrm{~kW}$.

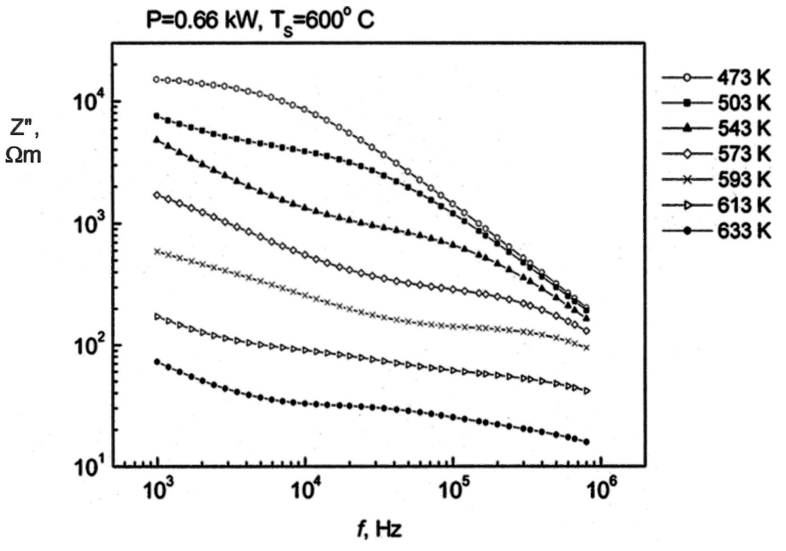

(a)

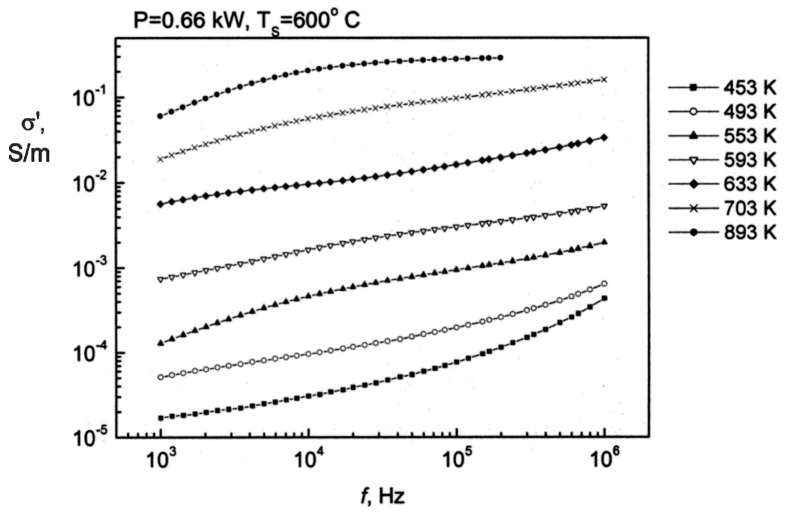

(b)

Fig. 3. Frequency dependences of (a) imaginary part of complex impedance $\operatorname{Im}(\tilde{Z})$ and $(\mathrm{b})$ real part of complex conductivity $\operatorname{Re}(\tilde{\sigma})$ of YSZ thin films (e-beam gun power $P=0.66 \mathrm{~kW}$, substrate temperature $T_{\mathrm{s}}=600^{\circ} \mathrm{C}$ ) at different temperatures.

Ionic conductivities at different temperatures were derived from impedance and conductivity spectra of the thin films using the nonlinear least squares fitting pro- cedures. Temperature dependences of bulk conductivity $\sigma_{\mathrm{b}}$ and characteristic total conductivity $\sigma_{\mathrm{t}}$ for investigated YSZ thin films deposed on Alloy-600 substrates are shown in Figs. 4(a) and 4(b) respectively.

The activation energies of $\sigma_{\mathrm{t}}$ and $\sigma_{\mathrm{b}}$ were found from the slopes of the Arrhenius plots. The values of conductivities and the corresponding activation energy depended on the technological conditions of the film depositions. The values of the bulk conductivity and corresponding activation energies $\Delta E_{\mathrm{b}}$ at the temperature $T=660 \mathrm{~K}$ are presented in Table 1 . The value of $\sigma_{\mathrm{t}}$ of YSZ thin films $\left(T_{\mathrm{s}}=400^{\circ} \mathrm{C}, P=0.9 \mathrm{~kW}\right)$ was found to be $5.9 \cdot 10^{-4} \mathrm{~S} / \mathrm{m}$ at $T=660 \mathrm{~K}$ and increased with temperature with activation energy $\Delta E_{\mathrm{t}}=1.1 \mathrm{eV}$. Crystallite size has an influence on the electrical conductivity: $\sigma_{\mathrm{b}}$ is the highest when crystallites are the biggest (Table 1).

The temperature dependences of the relaxation processes (at characteristic frequencies) in YSZ thin films bulk were obtained from the maximum of $\operatorname{Im}(\tilde{Z})(f)$ curves measured at different temperatures. The temperature dependences of the bulk dispersion $\sigma_{\mathrm{b}}$ relaxation frequency $f_{\mathrm{b}}$ are presented in Fig. 5 .

The data from Table 1 and the results in Fig. 5 show that the values of activation energy of the relaxation dispersion frequency, $\Delta E_{f}$, and the values of activation energy of the bulk conductivity, $\Delta E_{\mathrm{b}}$, of the YSZ thin films are very similar.

The ionic conductivity $\sigma_{\mathrm{b}}$ of YSZ thin films which is due to the migration of vacant oxygen sites is expressed as the product of the volume concentration $N$, mobility 
Table 1 . Ionic conductivity $\sigma_{\mathrm{b}}$ and the corresponding activation energy $\Delta E_{\mathrm{b}}$ of YSZ thin films deposited at different technological conditions $(P$ is e-beam gun power, $T_{\mathrm{s}}$ is substrate temperature during the deposition, $d$ is crystallite size extracted from XRD data) at temperature $T=660 \mathrm{~K}$.

\begin{tabular}{cccc}
\hline Technological parameters & Crystallite size $d, \mathrm{~nm}$ & $\sigma_{\mathrm{b}}, \mathrm{S} / \mathrm{m}$ & $\Delta E_{\mathrm{b}}, \mathrm{eV}$ \\
\hline$T_{\mathrm{s}}=250^{\circ} \mathrm{C}, P=0.66 \mathrm{~kW}$ & 17.2 & $9.6 \cdot 10^{-4}$ & 1.1 \\
$T_{\mathrm{s}}=600^{\circ} \mathrm{C}, P=0.66 \mathrm{~kW}$ & 34.1 & $3.44 \cdot 10^{-3}$ & 0.90 \\
$T_{\mathrm{s}}=250^{\circ} \mathrm{C}, P=0.9 \mathrm{~kW}$ & 18.7 & $5.7 \cdot 10^{-4}$ & 1.1 \\
$T_{\mathrm{s}}=400^{\circ} \mathrm{C}, P=0.9 \mathrm{~kW}$ & 22.1 & $1.1 \cdot 10^{-3}$ & 0.87 \\
$T_{\mathrm{s}}=600^{\circ} \mathrm{C}, P=0.9 \mathrm{~kW}$ & 37.9 & $4.12 \cdot 10^{-3}$ & 0.95 \\
\hline
\end{tabular}

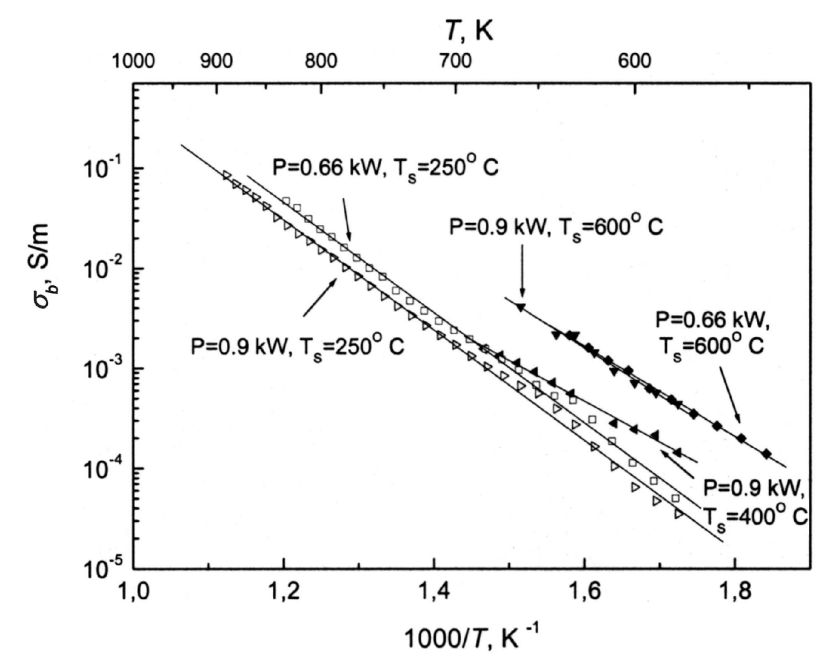

(a)

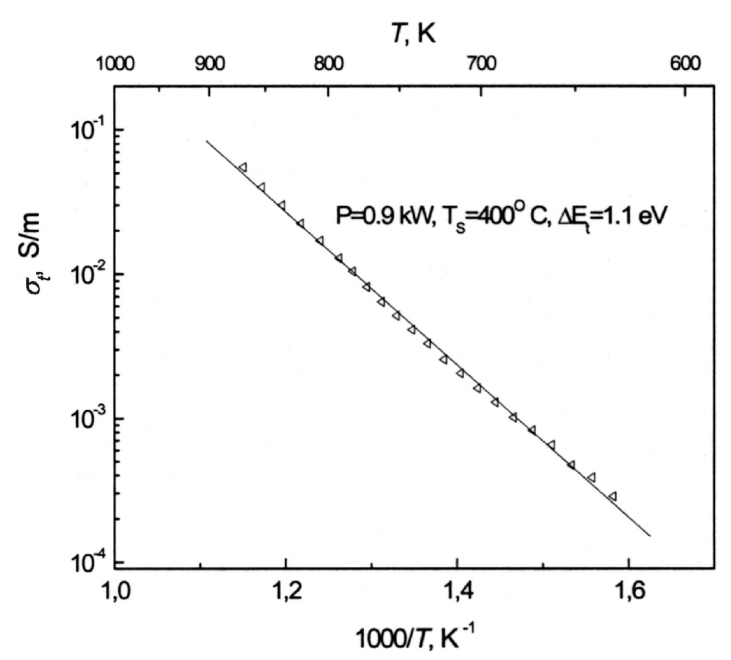

(b)

Fig. 4. Temperature dependences of (a) the bulk conductivity at different technological parameters ( $P$ is e-beam gun power, $T_{\mathrm{s}}$ is substrate temperature during the deposition) and (b) of the total conductivity at $P=0.9 \mathrm{~kW}, T_{\mathrm{s}}=400{ }^{\circ} \mathrm{C}$ thin films deposited on Alloy- 600 substrates.

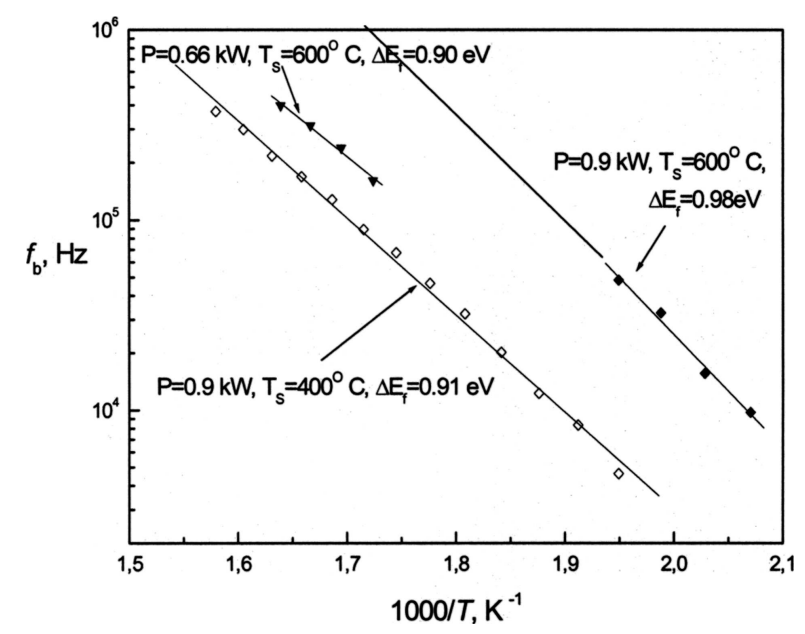

Fig. 5. Characteristic temperature dependences of relaxation frequency of the dispersion $\sigma_{\mathrm{b}}$ of YSZ thin films deposited on Alloy600 (the temperature curve of $f_{\mathrm{b}}$ for thin films deposited at $T_{\mathrm{s}}=$ $600{ }^{\circ} \mathrm{C}, P=0.9 \mathrm{~kW}$ is extrapolated to temperature $T=578 \mathrm{~K}$ ).

$\mu$, valence of the charged oxygen vacancies $z(z=2)$, and electric charge $q=1.6 \cdot 10^{-19} \mathrm{C}$ :

$$
\sigma_{\mathrm{b}}=q z N \mu=\sigma_{0} \exp \left(-\frac{\Delta E_{\mathrm{b}}}{k T}\right),
$$

where $k=1.38 \cdot 10^{-23} \mathrm{~J} / \mathrm{K}$ is Boltzmann constant. From conductivity measurements it is therefore not possible to clarify which of the two contributions $(N$ or $\mu$ ) is responsible for the conductivity increase with increasing temperature. The volume concentration of extrinsic oxygen vacancies $N_{0}$ is originating from doping the $\mathrm{ZrO}_{2}$ with trivalent $\mathrm{Y}_{2} \mathrm{O}_{3}$ according to the following equation:

$$
\mathrm{Y}_{2} \mathrm{O}_{3}=2 \mathrm{Y}_{\mathrm{Zr}}^{\prime}+\mathrm{V}_{\mathrm{O}}^{* *}+3 \mathrm{O}_{\mathrm{O}}
$$

The total concentration of all extrinsic oxygen vacancies created by the $\mathrm{Y}$ substitution, $N_{0}$, can be calculated according to Ref. [13]. If the ion transport process is attributed to jumps of free oxygen vacancies in the lattice [8], their mobility $\mu$ can be analysed. The diffusion coefficient of oxygen vacancies, $D_{\mathrm{v}}$, is related to the relaxation frequency $\omega_{\mathrm{R}}[8]$ according to the random walk model of thermally activated jumps. The mobility is related to the diffusion coefficient $D_{\mathrm{v}}$ via the Nernst-Einstein relation.

It is possible to calculate the number of oxygen vacancies taking part in the charge transport from 
Table 2. Charge carriers' transport properties (concentration of mobile charge carriers $N$, diffusion coefficient $D_{\mathrm{v}}$, ionic conductivity $\sigma_{\mathrm{b}}$, mobility of oxygen vacancies $\mu$ from relations, and the relaxation frequency $f_{\mathrm{b}}$ of the migration processes of charge carriers) of YSZ thin films deposited at different technological parameters ( $P$ is e-beam gun power, $T_{\mathrm{s}}$ is substrate temperature during the deposition) at temperature $T=578 \mathrm{~K}$.

\begin{tabular}{ccccccc}
\hline Technological parameters & Crystallite size $d, \mathrm{~nm}$ & $N, \mathrm{~m}^{-3}$ & $D_{\mathrm{v}}, \mathrm{m}^{2} / \mathrm{s}$ & $\mu, \mathrm{m}^{2} /(\mathrm{V} \cdot \mathrm{s})$ & $\sigma_{\mathrm{b}}, \mathrm{S} / \mathrm{m}$ & $f_{\mathrm{b}}, \mathrm{Hz}$ \\
\hline$T_{\mathrm{s}}=600^{\circ} \mathrm{C}, P=0.66 \mathrm{~kW}$ & 34.1 & $2.38 \cdot 10^{27}$ & $1.4 \cdot 10^{-14}$ & $2.85 \cdot 10^{-13}$ & $4.34 \cdot 10^{-4}$ & $1.469 \cdot 10^{5}$ \\
$T_{\mathrm{s}}=400^{\circ} \mathrm{C}, P=0.9 \mathrm{~kW}$ & 22.1 & $5.9 \cdot 10^{26}$ & $7.2 \cdot 10^{-15}$ & $1.44 \cdot 10^{-13}$ & $5.43 \cdot 10^{-5}$ & $7.437 \cdot 10^{4}$ \\
$T_{\mathrm{s}}=600^{\circ} \mathrm{C}, P=0.9 \mathrm{~kW}$ & 37.9 & $3.95 \cdot 10^{26}$ & $9.05 \cdot 10^{-14}$ & $1.82 \cdot 10^{-12}$ & $4.59 \cdot 10^{-4}$ & $9.356 \cdot 10^{5}$ \\
\hline
\end{tabular}

experimental values of both the ionic conductivity $\sigma_{\mathrm{b}}$ and relaxation frequency $\omega_{\mathrm{R}}$. The concentration $N$ of mobile charge is

$$
N=\frac{6 k T \sigma_{\mathrm{b}}}{z^{2} q^{2} \gamma l^{2} \omega_{R}}
$$

where $l^{2}$ is the mean square jump distance between anion sites in the crystal lattice, $\gamma$ is correlation factor depending on the definition and probability population of jump vectors, and $1 / 6$ is geometric factor for the cubic site symmetry, $\omega_{\mathrm{R}}=2 \pi f_{\mathrm{b}}$. Since for the YSZ thin films $\Delta E_{\mathrm{b}} \cong \Delta E_{f}$, it gives the evidence that the dependence $\sigma_{\mathrm{b}}(T)$ of YSZ thin films is caused by the temperature dependence of oxygen vacancy mobility, while the number of charge carriers remains constant with temperature.

Therefore it can be concluded that the concentration of charge carriers is independent on temperature in the investigated range of the temperature. This indicates that the theoretical volume vacancy concentration for YSZ thin films has been found to be $N_{0}=$ $1.2 \cdot 10^{29} \mathrm{~m}^{-3}$. Assuming $\gamma l^{2}=0.35 a^{2}[1,8]$, the concentration of mobile charge carriers $N$, diffusion coefficient $D_{\mathrm{v}}$, and mobility of oxygen vacancies $\mu$ from relations, and the relaxation frequency of the migration processes $f_{\mathrm{b}}$ of charge carriers can be calculated. The values of $N, D_{\mathrm{v}}, \mu, \sigma_{\mathrm{b}}$, and $f_{\mathrm{b}}$ of charge carriers for YSZ thin films deposited at different technological parameters $\left(P\right.$, e-beam gun power, and $T_{\mathrm{s}}$, substrate temperature during the deposition) at temperature $T=$ $578 \mathrm{~K}$ are summarized in Table 2.

The different charge transport properties of YSZ films can be caused by the change of technological conditions at deposition of the films. The characteristic changes of charge carrier transport properties of YSZ ceramics are caused by different stoichiometric factor of the material [2].

The temperature dependences of the real part of complex dielectric permittivity $\varepsilon^{\prime}$ were investigated at the frequency of $1 \mathrm{GHz}$. This frequency is higher than Maxwell relaxation frequency $f_{\mathrm{M}}=\sigma_{\mathrm{b}} /\left(2 \pi \varepsilon_{0} \varepsilon^{\prime}\right)$, where $\varepsilon_{0}=8.85 \cdot 10^{-12} \mathrm{~F} / \mathrm{m}$ is dielectric constant of the vacuum. $f_{\mathrm{M}}$ is dependent on YSZ thin films preparation conditions and it changes in the range from 0.2 to $1.7 \mathrm{MHz}$ at temperature $T=660 \mathrm{~K}$. The real part of complex permittivity was found to be $\varepsilon^{\prime}=21$ at $T=$ $300 \mathrm{~K}$. The increase of $\varepsilon^{\prime}$ value with temperature can be the reason of the migration polarization of oxygen vacancies, vibration of lattice, and electronic polarization.

\section{Conclusions}

The thin films of $\mathrm{ZrO}_{2}-8$ mol\% $\mathrm{Y}_{2} \mathrm{O}_{3}$ have been deposited by e-beam technique. The Alloy-600 and optical quartz were used as substrates for thin films deposition. SEM study has shown that thin films have cracks at higher e-beam power, when the growing rate is higher than $1.5 \mathrm{~nm} / \mathrm{s}$, and small isolated islands. Investigation of the $\mathrm{X}$-ray diffraction patterns has shown that thin films are in tetragonal phase and repeat the crystal structure of the chosen evaporated YSZ material. Two relaxation dispersions of ionic conductivity in the thin films have been found. The relaxation process has been related to $\mathrm{V}_{\mathrm{O}}^{* *}$ transport in the grain boundary and bulk of the films. The temperature dependence of bulk ionic conductivity of the films is caused by oxygen vacancies' mobility, while the concentration of the charge carriers remains constant with temperature. The charge carriers' transport properties depend on technological conditions of depositions thin films. The value of $\varepsilon^{\prime}$ of YSZ films was related to contribution of the migration polarization of oxygen vacancies, vibration of lattice, and electronic polarization. The highest ionic conductivity $\sigma_{\mathrm{b}}$ was found in the YSZ thin films deposited at $T_{\mathrm{s}}=600^{\circ} \mathrm{C}, P=0.9 \mathrm{~kW}$. The concentration of mobile charge carriers, diffusion coefficient, mobility of oxygen vacancies, and ionic conductivity depend on technological parameters: e-beam gun power and substrate temperature during the deposition of YSZ thin films. 


\section{Acknowledgement}

The Lithuanian State Science and Studies Foundation supported this work.

\section{References}

[1] R.P. Ingel and D. Lewis, J. Am. Ceram. Soc. 69, 325 (1986).

[2] A. Orliukas, K. Sasaki, P. Bohac, and L.J. Gauckler, in: Proceedings of the Second International Symposium on Solid Oxide Fuel Cells, 2-5 July 1991, Athens, Greece (1991), p. 377.

[3] P. Bohac, A. Orliukas, and L.J. Gauckler, in: Proceedings of the 1st European Solid Oxide Fuel Cells Forum, 3-7 October 1994, Lucerne, Switzerland, Vol. 2, ed. U. Bossel (1994), p. 651.

[4] F. Jones, J. Vac. Sci. Technol. 6, 3088 (1988).

[5] D. Milcius, L.L. Pranevicius, V. Sirvinskaite, T. Salkus, A. Kezionis, and A.F. Orliukas, Solid State Phenom. 97-98, 153 (2004).
[6] G. Laukaitis, J. Dudonis, and D. Milcius, Thin Solid Films (2005, in press).

[7] G. Laukaitis and J. Dudonis, Materials Science (Medžiagotyra) 11, 9 (2005).

[8] A. Orliukas, P. Bohac, K. Sasaki, and L.J. Gauckler, Solid State Ionics 72, 35 (1994).

[9] R. Sobiestianskas, A. Dindune, Z. Kanepe, J. Ronis, A. Kežionis, E. Kazakevičius, and A. Orliukas, Mater. Sci. Eng. B 76, 184 (2000).

[10] W. Bogusz, J.R. Dygas, F. Krok, A. Kezionis, R. Sobiestianskas, E. Kazakevicius, and A. Orliukas, Phys. Status Solidi 183, 323 (2001).

[11] M. Cretin and P. Fabry, J. Eur. Ceram. Soc. 19, 2931 (1999).

[12] M. Gödichemeier, B. Michel, A. Orliukas, P. Bohac, K. Sasaki, L. Gauckler, H. Heinrich, P. Schwander, G. Kostorz, H. Hofmann, and O. Frei, J. Mater. Res. 9, 1228 (1994).

[13] D.K. Honke, in: Fast Ion Transport in Solids, ed. P. Vashita, J.N. Mundy, and G.K. Sheenoy (North Holland, 1979) p. 699.

\title{
ELEKTRONŲ PLUOŠTU UŽGARINTU ITRIU STABILIZUOTO CIRKONIO OKSIDO PLONŲJŲ SLUOKSNIŲ JONINIS LAIDUMAS
}

\author{
G. Laukaitis ${ }^{\text {a }}$, J. Dudonis ${ }^{\text {a }}$, O. Liukpetryte ${ }^{\text {a }}$, A.F. Orliukas ${ }^{\text {b }}$, D. Milčius ${ }^{c}$ \\ ${ }^{\text {a }}$ Kauno technologijos universiteto Fundamentaliuju mokslu fakultetas, Kaunas, Lietuva \\ ${ }^{\mathrm{b}}$ Vilniaus universiteto Fizikos fakultetas, Vilnius, Lietuva \\ ${ }^{\mathrm{c}}$ Lietuvos energetikos institutas, Kaunas, Lietuva
}

\begin{abstract}
Santrauka
Norint sumažinti kuro elementų darbo temperatūrą iki 600 $800{ }^{\circ} \mathrm{C}$ bei išlaikyti tą pati jonini laidumą kaip ir $1000^{\circ} \mathrm{C}$ temperatūroje $(0,16 \mathrm{~S} / \mathrm{cm})$, yra mažinamas elektrolitų storis iki 1-2 $\mu \mathrm{m}$. Cirkonio oksido, stabilizuoto itriu, (YSZ) deguonies jonų laidumas priklauso nuo daugelio faktorių, t. y. nuo temperatūros, itrio molinès koncentracijos, elektrolito darbo laiko, $\mathrm{O}_{2-}$ jonų koncentracijos, $\mathrm{O}_{2}$ - jonų difuzijos koeficiento, kristalitų dydžio bei nuo kristalografinès grūdeliu padèties. Šiuos parametrus galima kontroliuoti, naudojant vakuuminius fizikinius dangų formavimo metodus.

YSZ ploni sluoksniai buvo nusodinami, elektroniniu spinduliu garinant tetragoninès fazès cirkonio oksido stabilizuoto $8 \mathrm{~mol} \%$ itrio (8YSZ) 1,68 $\mu \mathrm{m}$ dalelių dydžio miltelius. Darbe nagrinèjama
\end{abstract}

elektroninio spindulio galios ir padèklo temperatūros įtaka suformuotų plonų YSZ sluoksnių savybèms, kristalinei sandarai, kristalitų dydžiui bei mikrosandarai. YSZ sluoksniai $(1,5-2 \mu \mathrm{m})$ buvo nusodinami ant skirtingos temperatūros $\left(250,400,600^{\circ} \mathrm{C}\right)$ optinio kvarco $\left(\mathrm{SiO}_{2}\right)$ padèklų, esant $0,66,0,9,1,05$ ir $1,2 \mathrm{~kW}$ elektronų spindulio galiai. Ploni sluoksniai buvo analizuojami Rentgeno spindulių difrakcijos ir skenuojančios elektroninès mikroskopijos metodais bei buvo atlikti joninio laidžio matavimai. Nustatyta, kad, keičiant elektronų spindulio galią ir padèklo temperatūrą, galima kontroliuoti YSZ plonų sluoksnių kristalitu dydžius (vyrauja $12-46 \mathrm{~nm}$ dydžio kristalitai). Suformuotu plonų sluoksniu joninis laidis bei jo aktyvacijos energija gaunami artimi kaip ir YSZ keramikoms, suformuotoms kitais metodais. 